\title{
INDEKS RESILIENSI TERUMBU KARANG DENGAN PENDEKATAN SISTEM SOSIAL- EKOLOGI: STUDI KASUS KKPD PULO PASI GUSUNG, SELAYAR
}

\author{
Suryo Kusumo ${ }^{a^{*}}$, Luky Adrianto $^{\mathrm{b}}$, Mennofatria Boer $^{\mathrm{b}}$, Suharsono $^{\mathrm{c}}$ \\ ${ }^{a}$ Mahasiwa Doktor Program Studi Pengelolan Sumberdaya Pesisir dan Laut, Sekolah Pascasarjana IPB, Jalan \\ Lingkar Kampus Dramaga, Bogor 16680 Indonesia \\ ${ }^{\mathrm{b}}$ Departemen Manajemen Sumberdaya Perairan, Fakultas Perikanan dan Ilmu Kelautan IPB, Jalan Lingkar \\ Kampus Dramaga, Bogor 16680 Indonesia \\ ${ }^{\mathrm{c}}$ Pusat Penelitian Oseanografi LIPI, Jalan Raya Pasir Putih No.1, Ancol, Jakarta, Indonesia \\ *Koresponden penulis : suryo_kusumo@apps.ipb.ac.id
}

\begin{abstract}
Abstrak
Pemanfaatan sumber daya pesisir, terutama sumber daya terumbu karang, merupakan mata pencaharian utama masyarakat Kawasan Konservasi Perairan Daerah Pulo Pasi Gusung, Selayar, Sulawesi Selatan. Ikan karang merupakan sumberdaya utama yang dimanfaatkan, bukan hanya dilakukan secara tradisional menggunakan alat tangkap ramah lingkungan, akan tetapi juga masih ditemukannya penggunaan sianida yang dapat mengancam ekosistem terumbu karang. Resiliensi terumbu karang bukan hanya tergantung pada faktor ekologi, akan tetapi juga faktor sosial dan ekonomi, dimana pemanfaatan sumberdaya ikan karang merupakan mata pencaharian utama masyarakat. Studi ini bertujuan untuk mengembangkan indeks resiliensi terumbu karang menggunakan pendekatan sistem sosial-ekologi. Indikator yang mempengaruhi resiliensi terumbu karang adalah tutupan karang hidup, tutupan alga, tutupan pasir dan rubble, biomassa ikan karang, upaya penangkapan ikan dengan sianida dan pendapatan yang diperoleh oleh nelayan. Indeks resiliensi terumbu karang pada waktu pengamatan menunjukkan nilai 3,2138 pada Desember 2016 hingga 3,7025 pada Juli 2018. Potensi pemulihan terumbu karang menujukkan kecenderungan semakin membaik, meskipun pada kategori sedang.
\end{abstract}

Kata kunci: indeks resiliensi, kawasan konservasi perairan daerah, sistem sosial-ekologi, selayar, terumbu karang.

\begin{abstract}
Utilization of coastal resources, especially coral reef, is the main livelihood of the people at Local Marine Conservation Area Pulo Pasi Gusung, Selayar, South of Sulawesi. Coral reef fish is the main resource that is utilized, not only traditionally, but also the use of cyanide which can threaten coral reef ecosystems. Resilience of coral reefs depends not only on ecological factor, but also social and economic factors, where the utilization of coral reef fish resources is the main livelihood of the community. The objective of this study to develop a resilience index of coral reefs using a social-ecological system approach. Indicators that affect the resilience of coral reefs are live coral cover, algae cover, sand and rubble cover, coral reef fish biomass, cyanide fishing efforts and income earned by fishermen. The resilience index of coral reefs at the time of observation showed a value of 3.2138 in December 2016 to 3.7025 in July 2018. Potential recovery of coral reefs showed a tendency to improve, even in the fair category.
\end{abstract}

Keywords: coral reef, local marine conservation area, resilience index, selayar, social-ecological system.

\section{PENDAHULUAN}

Barang dan jasa dari ekosistem terumbu karang merupakan hal utama yang menopang kesejahteraan sosial dan ekonomi masyarakat pesisir. Faktor-faktor sosial dan ekonomi sangat mempengaruhi kondisi ekosistem terumbu karang. Diperlukan pemahaman dengan pendekatan sistem sosial-ekologi didalam menangani masalah penurunan kondisi ekosistem terumbu karang serta menentukan penyebab utama dari faktor sosial-ekonomi yang kompleks yang mempengaruhi bagaimana masyarakat memanfaatkan dan mengelola sumberdaya terumbu karang [1].

Sebagai upaya mengatasi degradasi sumber daya kelautan di Indonesia, diperlukan 
suatu desain pengelolaan yang komprehensif, yang tidak hanya mempertimbangkan kemampuan sumberdaya terumbu karang untuk dapat pulih kembali setelah mengalami penurunan serta faktor-faktor pendukung lainnya juga perlu dipertimbangkan aspek sosial-ekonomi dari masyarakat yang memanfaatkannya. Dinamika terumbu karang berkaitan erat dengan apa yang terjadi dalam sosial-ekonomi masyarakat. Variabel sosial-ekonomi merupakan salah satu penggerak perubahan ekologi [2].

Resiliensi merupakan respon ekosistem dan jaminan terhadap terjadinya perubahan lingkungan, dan telah menjadi tujuan utama dari pengelolaan terumbu karang. Keanekaragaman hayati, keanekaragaman spasial dan konektivitas diusulkan sebagai landasan resiliensi dan jaminan terhadap ketidakpastian ekologi. Indikator empiris yang dapat dijadikan sebagai landasan resiliensi antara lain: pelaku kolonisasi ruang, mengukur keanekaragaman spasial dan kapasitas grazing. Indikator operasional resiliensi ini digunakan sebagai perangkat didalam mengetahui kerentanan (vulnerability) sebelum terjadinya gangguan yang akan menyebabkan terjadi phase-shift [2].

Teori resiliensi telah berkembang didalam mempelajari perilaku dinamika ekosistem. Dibutuhkan operasionalisasi teori resiliensi, dalam hal ini resiliensi terumbu karang didalam pengelolaan wilayah pesisir. Indikator-indikator resiliensi terumbu karang dapat digunakan sebagai sinyal atau pertanda bagi pengelola terhadap kerentanan sumberdaya agar tidak mecapai titik kritis akibat adanya gangguan. Indikator-indikator tersebut juga digunakan didalam memahami resiliensi terumbu karang [2,3].

Penelitian ini bertujuan untuk mengembangkan indeks resiliensi terumbu karang dengan mempertimbangkan aspek sosial, ekonomi dan ekologi di KKPD Pulo Pasi Gusung, Kabupaten Kepulauan Selayar, Provinsi Sulawesi Selatan.

\section{MATERIAL DAN METODE 2.1. Lokasi dan Waktu}

Pulau Pasi Gusung memiliki luas $2.388,78$ ha, dengan garis pantai sepanjang 29.545,66 meter, luas mangrove 66,62 ha, terumbu karang 408,36 ha, terumbu karang bercampur dengan pasir 603.61 ha, padang lamun bercampur pasir 799.53 ha, hamparan pasir tergenang air laut 171.32 ha, hamparan pasir putih di pantai 58.95 ha, pemukiman 25.99 ha, kebun/kelapa 845.42 ha, dan tegalan/ladang 1391.40 ha [4].

P. Pasi Gusung merupakan Kawasan Konservasi Perairan Daerah sesuai dengan SK Bupati No. 466/IX/Tahun 2011 menjadi Taman Wisata Perairan. Luas kawasan konservasi perairan Pulo Pasing Gusung adalah 5.018 hektar. Saat ini kawasan konservasi perairan Pulo Pasi Gusung telah memiliki pengelola, yaitu Dinas Kelautan dan Perikanan dan rencana pengelolaan dan zonasi. Upaya-upaya pokok pengelolaan dan pembangunan sarana prasarana juga aktif dilaksanakan baik menggunakan dana APBD maupun APBN [5].

Lokasi penelitian terletak di sekitar perairan KKPD Pulo Pasi Gusung. Stasiun PG1 terletak di zona inti Ujung Lola, yaitu di bagian utara perairan P. Pasi Gusung. Stasiun PG2 terletak dekat dengan zona pemanfaatan Je'neiya, yaitu di bagian barat P. Pasi Gusung, dan Stasiun PG2 terletak di zona perikanan berkelanjutan, yaitu di bagian selatan P. Pasi Gusung. Lokasi stasiun penelitian dapat dilihat pada Gambar 1.

Penelitian dilaksanakan pada bulan September 2016 hingga bulan Desember 2018. Survei awal dilakukan pada bulan September 2016 untuk menentukan stasiun pengamatan. Pengambilan data pengamatan dilakukan pada bulan Desember 2016 hingga bulan Juli 2018. Pengambilan data lapangan meliputi pengamatan data terumbu karang, yaitu bentik dasar dan ikan karang, perekaman data suhu perairan laut dan pengambilan data sosial-ekonomi masyarakat nelayan di P. Pasi Gusung. 


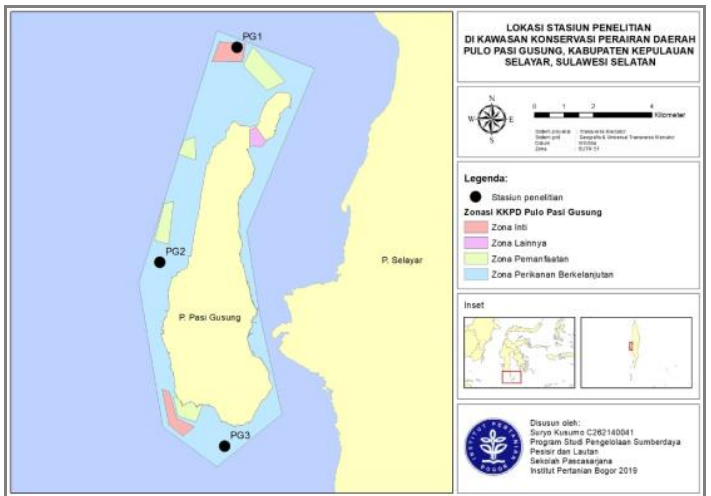

Gambar 1. Lokasi penelitian di KKPD Pulo Pasi Gusung, Kabupaten Kep. Selayar, Sulawesi Selatan.

\section{Metode Pengambilan dan Analisis Data}

\section{1) Indikator Resiliensi Terumbu karang}

Kesehatan terumbu karang tidak hanya digambarkan dengan kondisi tutupan karang hidup. Kegiatan COREMAP yang dilakukan menunjukkan bahwa terdapat suatu lokasi dimana tutupan karang hidup yang rendah tetapi memiliki sumberdaya ikan terumbu karang yang tinggi, atau sebaliknya tutupan karang hidup yang tinggi tetapi sumberdaya ikan terumbu karangnya rendah. Oleh karena itu maka Pusat Penelitian Oseanografi LIPI dengan kegiatan COREMAP-CTI telah mengembangkan indikator kesehatan terumbu karang Indonesia. Indikator atau parameter yang banyak belum tentu menjamin nilai indeks yang akan dihasilkan akan lebih baik [6].

Didalam penelitian ini, indikator resiliensi terumbu karang dikembangkan untuk KKPD Pulo Pasi Gusung mengacu pada indikator yang telah ditetapkan LIPI dan ditambah dengan parameter sosial dan ekonomi masyarakat di P. Pasi Gusung, yaitu upaya penangkapan ikan terumbu karang dengan menggunakan bius dan pendapatan per trip yang diperoleh nelayan dari menangkap ikan di sekitar perairan Pasi Gusung (Gambar 2). Kedua parameter tersebut sangat mempengaruhi kondisi atau kualitas terumbu karang. Selain penangkapan ikan dengan cara tradisional menggunakan pancing, penggunaan bius untuk menangkap ikan masih tetap ada yang melakukannya. Data tentang upaya penangkapan ikan dengan menggunakan bius dan pendapatan nelayan diperoleh dengan melakukan wawancara dan kuesioner kepada nelayan di P. Pasi Gusung.

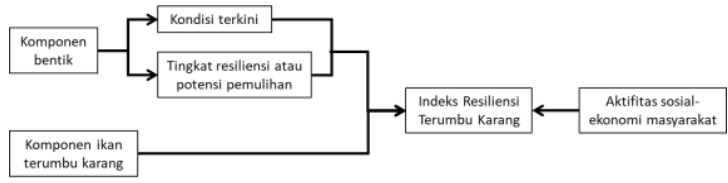

Gambar 2. Indikator yang digunakan didalam mengembangkan indeks resiliensi terumbu karang (modifikasi dari [5]).

Pengambilan data indikator resiliensi terumbu karang dilakukan pengamatan dilakukan selama 20 bulan, yaitu dimulai pada Desember 2016 hingga Juli 2018 dimana pengambilan data dilakukan setiap 2-5 bulan sekali. Pengambilan data dilakukan dengan metode Underwater Photo Transect [7]. Lamanya waktu pengamatan tersebut diharapkan dapat mewakili kondisi musim di sekitar perairan P. Pasi Gusung selama 20 bulan, Pengamatan dilakukan pada 3 stasiun pada kedalaman $5-7 \mathrm{~m}$.

Kategori bentuk pertumbuhan karang dan biota bentik menggunakan panduan monitoring survey bentik dasar laut [8]. Identifikasi jenis/genera karang menggunakan jenis-jenis karang di Indonesia [9]. Selanjutnya data tersebut diolah dan dianalisis menggunakan perangkat lunak PhotoQuad versi $1.4[10]$.

Pencatatan data ikan terumbu dilakukan dengan metode Visual Census (VC) menggunakan transek sepanjang $50 \mathrm{~m}$ dan lebar $5 \mathrm{~m}$ [8]. Pencatatan data ikan terumbu hanya difokuskan pada genus/spesies dari 7 (tujuh) suku ikan terumbu, yaitu Chaetodontidae (kepe-kepe), Serranidae (kerapu), Lutjanidae (kakap), Lethrinidae (lencam), Haemulidae (bibir tebal), Scaridae (kakatua) dan Siganidae (beronang) [11]. Pencatatan data meliputi genus/spesies dan jumlah ikan setiap genus/spesies. Untuk identifikasi ikan menggunakan jenis-jenis ikan di daerah tropis [12] dan pedoman monitoring ikan terumbu karang LIPI [11].

Data indikator sosial-ekonomi diperoleh dengan metode wawancara dan kuesioner dengan responden 110 orang nelayan yang bertempat tinggal di 3 desa, yaitu Desa 
Bontolebang, Desa Kahu-Kahu dan Desa Bontoborusu. Data indikator resiliensi terumbu karang yang dikembangkan didalam penelitian ini seperti pada tabel berikut:

Tabel 1. Indikator indeks resiliensi terumbu karang di KKPD Pulo Pasi Gusung.

\begin{tabular}{clcc}
\hline No. & $\quad$ Nama indikator & Satuan & $\begin{array}{c}\text { Metode } \\
\text { pengambilan } \\
\text { data }\end{array}$ \\
\hline 1 & $\begin{array}{l}\text { Tutupan karang } \\
\text { hidup }\end{array}$ & $\%$ & Underwater \\
2 & $\begin{array}{l}\text { Tutupan alga } \\
\text { Tutupan pasir dan } \\
\text { rubble }\end{array}$ & $\%$ & $\begin{array}{c}\text { Photo } \\
\text { Transect }\end{array}$ \\
4 & $\begin{array}{l}\text { Total biomassa } \\
\text { ikan karang }\end{array}$ & $\mathrm{kg} / 100$ & $\begin{array}{c}\text { Underwater } \\
\text { visual census }\end{array}$ \\
5 & $\begin{array}{l}\text { Upaya } \\
\text { penangkapan ikan } \\
\text { karang dengan bius }\end{array}$ & trip & $\begin{array}{l}\text { Wawancara, } \\
\text { focus group }\end{array}$ \\
& $\begin{array}{l}\text { Pendapatan bersih } \\
\text { nelayan }\end{array}$ & Rp./trip & $\begin{array}{c}\text { discussion dan } \\
\text { kuesioner }\end{array}$ \\
\hline
\end{tabular}

\section{2) Perhitungan Indeks Resiliensi Terumbu Karang}

Perhitungan indeks resiliensi terumbu karang (IRTK) menggunakan pendekatan cost-benefit indicators [13]. Indikator resiliensi dibagi menjadi 2 kategori, yaitu benefit indicators dan cost indicators. Benefit indicators adalah indikator-indikator yang mendukung resiliensi terumbu karang, sedangkan cost indicators adalah indikatorindikator yang mengurangi resiliensi. Formulasi cost-benefit indicators seperti pada formulasi berikut:

$$
\begin{aligned}
& X_{\text {benefit }}=\frac{\left(X-X_{\min }\right)}{\left(X_{\max }-X_{\min }\right)} \\
& X_{\text {cost }}=\frac{\left(X_{\max }-x\right)}{\left(X_{\max }-X_{\min }\right)} \\
& \text { IRTK }=\sum_{i=1}^{n} \frac{\left(X_{\text {benefit }}+X_{\text {cost }}\right)}{n}
\end{aligned}
$$

dimana $X_{\text {benefit }}=$ indeks untuk benefit indicators; $X_{\text {cost }}=$ indeks untuk cost indicators; $X_{\max }=$ nilai maksimum pada indikator; $X_{\min }=$ nilai minimum pada indikator; $X=$ nilai indikator; IRTK = indeks resiliensi terumbu karang; $n=$ total jumlah parameter
Untuk menentukan indikator benefit dan cost maka dilakukan analisis komponen utama (Principle Component Analysis/PCA) dari seluruh data data pengamatan. Korelasi dan vektor ciri dari hasil analisis PCA serta proyeksi dari vektor ciri digunakan untuk menentukan indikator benefit dan cost.

Nilai indeks yang akan diperoleh akan berkisar antara $0-6$, maka klasifikasi indeks resiliensi terumbu karang dibagi menjadi 3 (tiga) kategori, yaitu: (1) potensi resiliensi rendah( IRTK $\leq 2$ ), (2) potensi resiliensi sedang $(2<$ IRTK $\leq 4)$ dan (3) potensi resiliensi tinggi $(4<$ IRTK $\leq 6)$.

\section{HASIL DAN PEMBAHASAN}

\section{Komponen Bentik}

Pengamatan komponen bentik terdiri dari tutupan karang hidup, tutupan alga dan tutupan pasir dan rubble. Pengamatan dilakukan pada bulan Desember 2016 hingga Juli 2018, dimana telah dilakukan 8 kali pengambilan data.

Data tutupan karang hidup pada setiap stasiun pengamatan dan total rerata dari ketiga stasiun menunjukkan bahwa tutupan karang hidup mengalami penurunan dan peningkatan, dimana terlihat indikasi adanya peningkatan tutupan karang hidup. Indikasi peningkatan tutupan karang hidup terlihat jelas pada Stasiun PG1. Meskipun terjadi penurunan pada PG2 dan tidak adanya data pada Nopember 2017 tapi terlihat tutupan karang hidup mulai untuk meningkat lagi. Pada Stasiun PG3 yang hanya dapat teramati sebanyak 4 kali tetapi menunjukkan kecenderungan adanya peningkatan tutupan karang hidup. Total rerata tutupan karang hidup menunjukkan kecenderungan peningkatan pada Desember 2016 hingga Nopember 2017, meskipun terjadi penurunan pada Mei 2018 tetapi terlihat tutupan karang hidup cenderung meningkat kembali. Total tutupan karang hidup dan tutupan setiap stasiun dapat dilihat pada Gambar 3.

Genus karang yang diamati di Stasiun PG1 antara lain: Acanthastrea, Acropora, Cyphastrea, Echinipora, Echinopora, Favia, Favites, Fungia, Galaxea, Goniastrea, Herpolitha, Leptoria, Leptoseris, Lobophyllia, 
Montastrea, Montipora, Oulophyllia, Platygyra, Pocillopora, Polyphyllia, Porites dan Symphyllia. Pada stasiun PG-2 diamati Acropora, Favia, Favites, Fungia, Galaxea, Goniastrea, Hydnophora, Leptoria, Lobophyllia, Montipora, Pocillopora, Porites, Seriatopora dan Stylophora. Genus karang yang diamati di Stasiun PG3 antara lain: Acropora, Favia, Favites, Fungia, Galaxea, Goniastrea, Herpolitha, Leptoseris, Millepora, Montipora, Pocillopora, Porites dan Stylophora. Gambar berikut memperlihatkan dinamika jumlah genus karang yang ditemui pada setiap stasiun pengamatan.

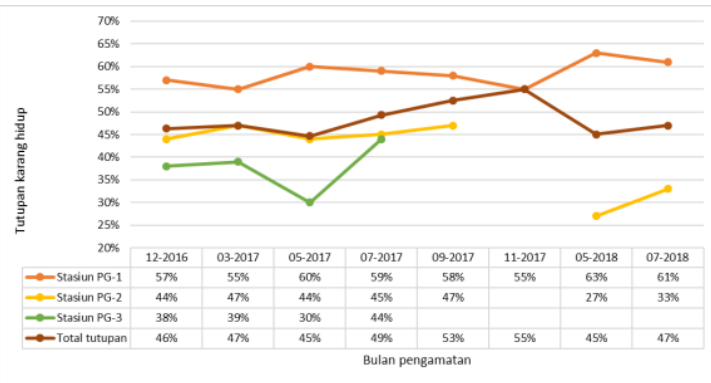

Gambar 1. Total tutupan karang hidup pada tiap stasiun pengamatan pada Desember 2016 - Juli 2018.

Tutupan alga pada Stasiun PG2 lebih tinggi dibandingkan stasiun lainnya. Tutupan alga pada Stasiun PG3 cenderung meningkat tetapi hanya dapat diamati dengan 4 pengamatan. Demikian juga tutupan alga pada Stasiun PG1 yang juga cenderung meningkat. Tutupan alga tertinggi diamati pada bulan Mei 2018 di Stasiun PG2 mencapai $57 \%$ dan terendah sebesar 3\% pada bulan Desember 2016 di Stasiun PG3. Tutupan alga sebagian besar berupa trusf alga dan alga yang menutupi karang mati.

Tutupan abiotik terdiri dari rubble, pasir dan batu. Tutupan abiotik didominasi oleh pasir dan rubble. Tutupan pasir dan rubble cenderung menurun pada Stasiun PG1 dan PG3, sedangkan pada Stasiun PG2 cenderung meningkat. Tutupan pasir dan rubble tertinggi diamati Stasiun PG3 pada Desember 2016 sebesar $49 \%$ dan terendah sebesar 5\% pada Juli 2018 di Stasiun PG1.

\section{Komponen Ikan Terumbu Karang}

Densitas ikan terumbu karang menunjukkan terjadinya kecenderungan penurunan pada setiap stasiun pengamatan. Densitas ikan herbivor dan ikan target pada stasiun PG1 relatif lebih tinggi dibandingkan dengan stasiun lainnya. Hal ini disebabkan karena lokasinya berada di zona inti KKPDPPG, sehingga sangat terbatas adanya aktifitas penangkapan ikan, meskipun masih banyak nelayan yang menangkap ikan di zona inti.

Densitas ikan herbivor didominasi oleh famili Acanthuridae untuk setiap stasiun pengamatan. Densitas ikan target didominasi oleh famili Acanthuridae. Terdapat 26 genus dan 100 spesies ikan terumbu karang yang diamati pada pengamatan Desember hingga Juli 2018 untuk semua stasiun pengamatan.

Biomassa ikan terumbu karang tertinggi yang diamati sebesar $307 \mathrm{~kg} / \mathrm{ha}$ di Stasiun PG1 pada Maret 2017 dan terendah sebesar 57 $\mathrm{kg} / \mathrm{ha}$ diamati di Stasiun PG2 pada Maret 2017. Total biomassa ikan terumbu karang cenderung menurun pada pengamatan Desember 2016 - Juli 2018. Demikian juga dengan rerata biomassa yang cenderung menurun pada akhir pengamatan. Berdasarkan kategori LIPI [6], maka biomassa ikan terumbu karang di perairan P. Pasi Gusung termasuk kategori rendah, dimana biomassa yang diamati kurang dari $970 \mathrm{~kg} / \mathrm{ha}$.

\subsection{Sosial Ekonomi Nelayan}

Mata pencaharian utama masyarakat di P. Pasi Gusung adalah nelayan. Kurang lebih sekitar $80 \%$ masyarakat bekerja sebagai nelayan, selain itu sebagai pedagang, pegawai desa dan buruh. Berdasarkan alat tangkap yang digunakan, maka 87,27\% menggunakan alat tangkap pancing ulur, $4,55 \%$ menggunakan pukat dan jaring serta 3,64\% menggunakan rawai.

Berdasarkan hasil kuesioner terhadap nelayan pancing, maka rerata pendapatan bersih yang diperoleh setiap kali menangkap ikan di perairan Pasi Gusung mencapai Rp. 394.159/trip pada bulan Februari dan terendah sebesar Rp. 101.306/trip pada bulan Juli. Pendapatan nelayan pancing dari menangkap ikan setiap trip di perairan Pasi Gusung cenderung tinggi pada awal tahun dan 
pertengahan tahun hingga Desember cenderung menurun. Upaya penangkapan ikan di perairan terdekat dilakukan untuk menambah pendapatan meskipun lokasinya relatif jauh dari pulau, seperti Patti Jahayya yang terletak di Desa Parak, pantai barat bagian selatan P. Selayar.

Berdasarkan hasil wawancara, maka terdapat kurang lebih 20 unit perahu nelayan bius. Jumlah hari maksimum untuk melakukan penangkapan dengan bius adalah 25 hari setiap bulannya, dengan lama aktifitas sekitar $4-8$ jam setiap harinya. Alternatif pekerjaan selain sebagai nelayan hanya tersedia $15 \%$ dari populasi nelayan. Luas zona inti dan zona pemanfaatan yang dilarang untuk melakukan penangkapan ikan sekitar $25 \%$ dari luas area terumbu karang. Untuk menduga upaya tangkap nelayan bius maka digunakan persamaan berikut: upaya nelayan bius $=$ jumlah perahu $\times$ peluang nelayan bius $\times$ jumlah hari melaut maksimal $\times$ jam melaut $\times(1-$ persentase pekerjaan alternatif $) \times(1$ - zona inti dan zona pemanfaatan)

\subsection{Perhitungan Indeks Resiliensi Terumbu Karang}

Berdasarkan data yang diperoleh, baik data ekologi, sosial dan ekonomi untuk indikator indeks resiliensi terumbu karang, maka dapat dilihat pada Tabel 2.

Selanjutnya dilakukan analisis komponen utama (PCA) untuk melihat seberapa besar komponen utama menggambarkan ragam data serta hubungan diantara indikator indeks resiliensi. Hasil analisis PCA dapat dilihat pada Tabel 3 dan Tabel 4.

Tabel 2. Indikator dan nilai indikator resiliensi terumbu karang.

\begin{tabular}{cccccccc}
\hline Bulan & $\begin{array}{c}\text { Tutupan } \\
\text { pasir dan } \\
\text { rubble }\end{array}$ & $\begin{array}{c}\text { Tutupan } \\
\text { karang } \\
\text { hidup }\end{array}$ & $\begin{array}{c}\text { Tutupan } \\
\text { alga }\end{array}$ & $\begin{array}{c}\text { Upaya } \\
\text { tangkap ikan } \\
\text { dengan bius }\end{array}$ & $\begin{array}{c}\text { Pendapatan } \\
\text { nelayan per trip }\end{array}$ & $\begin{array}{c}\text { Biomassa } \\
\text { ikan karang } \\
\left(\mathrm{kg} / 100 \mathrm{~m}^{2}\right)\end{array}$ \\
\hline $12-2016$ & $26 \%$ & $43 \%$ & $16 \%$ & 956 & $\mathrm{Rp}$ & 103,419 & 1.32 \\
$03-2017$ & $22 \%$ & $48 \%$ & $15 \%$ & 1,530 & $\mathrm{Rp}$ & 240,345 & 1.5 \\
$05-2017$ & $18 \%$ & $49 \%$ & $25 \%$ & 398 & $\mathrm{Rp}$ & 145,334 & 1.17 \\
$07-2017$ & $15 \%$ & $50 \%$ & $27 \%$ & 796 & $\mathrm{Rp}$ & 101,306 & 1.14 \\
$09-2017$ & $9 \%$ & $52 \%$ & $34 \%$ & 637 & $\mathrm{Rp}$ & 101,331 & 1.33 \\
$11-2017$ & $10 \%$ & $55 \%$ & $25 \%$ & 557 & $\mathrm{Rp}$ & 102,600 & 2.21 \\
$05-2018$ & $9 \%$ & $58 \%$ & $27 \%$ & 637 & $\mathrm{Rp}$ & 145,334 & 1.03 \\
$07-2018$ & $7 \%$ & $57 \%$ & $31 \%$ & 1,275 & $\mathrm{Rp}$ & 101,306 & 1.01 \\
\hline
\end{tabular}

Tabel 3. Akar ciri perhitungan indeks resiliensi terumbu karang.

\begin{tabular}{lcrrrrr}
\hline & F1 & F2 & F3 & F4 & F5 & F6 \\
\hline Eigenvalue & 3.059 & 1.309 & 0.994 & 0.514 & 0.116 & 0.007 \\
Variability (\%) & 50.980 & 21.816 & 16.568 & 8.575 & 1.938 & 0.124 \\
Cumulative \% & 50.980 & 72.796 & 89.364 & 97.939 & 99.876 & 100.000 \\
\hline
\end{tabular}

Tabel 4. Vektor ciri indikator indeks resiliensi terumbu karang.

\begin{tabular}{lcccccc}
\hline & F1 & F2 & F3 & F4 & F5 & F6 \\
\hline Tutupan pasir dan rubble & -0.539 & 0.227 & -0.197 & 0.017 & 0.052 & 0.785 \\
Tutupan karang hidup & 0.453 & -0.490 & 0.091 & -0.187 & -0.498 & 0.513 \\
Tutupan alga & 0.536 & 0.094 & 0.197 & 0.135 & 0.730 & 0.339 \\
Upaya tangkap ikan dengan bius & -0.296 & -0.489 & 0.391 & 0.720 & 0.032 & 0.019 \\
Pendapatan nelayan per trip & -0.360 & -0.414 & 0.384 & -0.652 & 0.353 & -0.041 \\
Biomassa ikan & 0.001 & 0.538 & 0.783 & -0.048 & -0.302 & 0.063 \\
\hline
\end{tabular}


Akar ciri hasil perhitungan PCA menunjukkan bahwa kompunen utama F1 memiliki nilai 3,059 yang menjelaskan $50,98 \%$ dari keragaman data dan komponen utama F2 sebesar 1,309 yang menjelaskan 21,82\%. Komponen F1 dan F2 dapat menjelaskan keragaman data sebesar 72,796\% (Tabel 3). Berdasarkan vektor ciri dari indikator indeks resiliensi terumbu karang, maka tutupan karang hidup, biomassa ikan dan tutupan alga merupakan benefit indicators, sedangkan tutupan rubble dan pasir, upaya penangkapan dengan bius dan pendapatan nelayan per trip merupakan cost indicators (Tabel 4).

Upaya tangkap nelayan bius dan pendapatan nelayan per trip tidak memiliki hubungan yang signifikan dengan tutupan karang hidup, biomassa ikan dan tutupan rubble dan pasir. Hal ini dibuktikan dengan nelayan tradisional dan nelayan bius selalu akan memangkap ikan, apakah hasilnya akan menguntungkan atau tidak, mereka tetap akan melaut. Hal tersebut sesuai dengan wawancara dengan nelayan bahwa mereka akan tetap melaut, meskipun hasilnya tidak menguntungkan dan tidak ada pekerjan alternatif selain sebagai nelayan.

Tutupan karang hidup dan tutupan pasir dan rubble dapat mencapai nilai maksimum $100 \%$, sedangkan tutupan alga dapat mencapai maksimal $65 \%$ berdasarkan data pengamatan. Total upaya tangkap nelayan bius maksimal adalah 4.800 trip per bulan. Pendapatan bersih nelayan maksimal mencapai Rp. 1.500.000,- per trip. Biomassa ikan maksimal mencapai $19,4 \mathrm{~kg} / 100 \mathrm{~m}^{2}$. Rumusan indeks resiliensi spasial terumbu karang dengan pendekatan sistem sosialekologi seperti pada persamaan (5).

Indeks Resiliensi Terumbu Karang
$=\sum_{i=1}^{6}($ tutupan karang hidup $)+\left(\frac{\text { tutupan alga }}{0.65}\right)+\left(\frac{\text { biomassa ikan karang }-0.01}{19.39}\right)+(1-$ tutupan pasir dan rubbble $)$
$\quad+\left(\frac{4800-\text { upaya penggunaan bius }}{480 n}\right)+\left(\frac{1500000-\text { pendapat nelayan per trip }}{1500000}\right)$

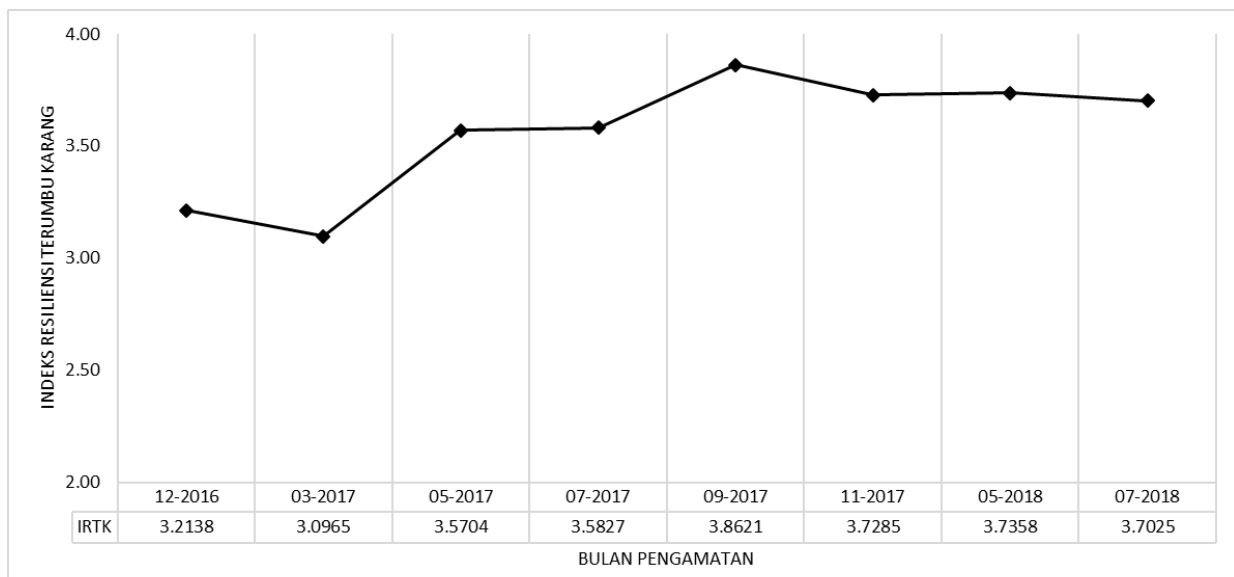

Gambar 2. Indeks resiliensi terumbu karang berdasarkan data pengamatan pada Desember 2016 - Juli 2018.

Berdasarkan perhitungan indeks resiliensi terumbu karang pada pengamatan Desember 2016 hingga Juli 2018, maka terjadi peningkatan potensi resiliensi. Pada Desember 2016 nilai indeks sebesar 3,2138 dan kemudian menurun pada Maret 2017 menjadi 3,0965. Pada pengamatan selanjutnya terlihat peningkatan nilai indeks hingga mencapai 3,8621 pada September
2017 dan cenderung menurun hingga Juli 2018 sebesar 3,7025 (Gambar 4).

Potensi resiliensi atau pemulihan terumbu karang di KKPD-PPG cenderung meningkat. Hal ini diduga disebabkan karena terjadinya peningkatan tutupan karang hidup dari $43 \%$ pada awal pengamatan hingga mencapai $57 \%$ pada akhir pengamatan. Selain itu juga terjadi peningkatan tutupan alga dari $16 \%$ menjadi 
$31 \%$ pada akhir pengamatan. Selain itu juga terjadi penurunan tutupan rubble dan pasir dari $26 \%$ menjadi $7 \%$ pada akhir pengamatan.

Apabila dibandingkan dengan indeks kesehatan terumbu karang yang diamati oleh LIPI, maka indeks resiliensi terumbu karang yang dikembangkan tidak memiliki perbedaan yang cukup signifikan. Berdasarkan hasil perhitungan LIPI pada tahun 2016 maka indeks yang diperoleh dari stasiun pengamatan terdekat dengan lokasi penelitian menunjukkan nilai indeks 6 (skala 1-10), yaitu tutupan karang hidup tinggi, potensi pemulihan yang tinggi dan kategori ikan terumbu karang yang rendah (Gambar 5). Indeks yang dikembangkan memiliki nilai kisaran antara 3,0965 hingga 3,8621 yaitu termasuk dalam kategori sedang.

Berdasarkan perbandingan dengan indeks kesehatan terumbu karang yang dikembangkan oleh LIPI, maka indeks resiliensi terumbu karang yang dikembangkan didalam penelitian ini menunjukkan keragaan yang relatif sama. Penambahan indikator sosial-ekonomi dapat digunakan didalam mengembangkan indeks penilaian dan potensi pemulihan ekosistem terumbu karang.

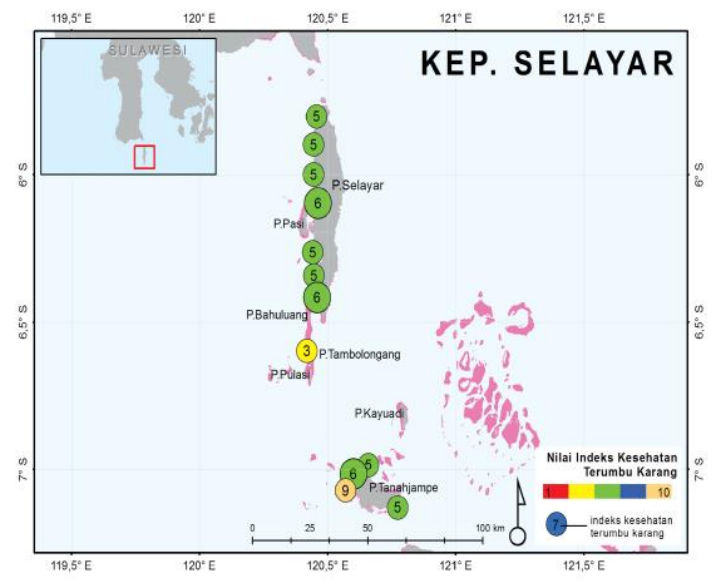

Gambar 3. Peta nilai indeks kesehatan terumbu karang di Kepulauan Selayar tahun 2016 [6].

\section{KeSIMPULAN}

Beberapa kesimpulan yang diperoleh dari penelitian ini antara lain:

1. Penilaian potensi pemulihan atau resiliensi terumbu karang tidak hanya menggunakan indikator ekologi, tetapi indikator sosial dan ekonomi juga dapat digunakan untuk melakukan penilaian resiliensi di Kawasan Konservasi Perairan Daerah Pulo Pasi Gusung, Selayar;

2. Indeks resiliensi terumbu karang yang dikembangkan dengan pendekatan sistem sosial-ekologi menghasilkan penilaian yang tidak jauh berbeda dengan indeks kesehatan terumbu karang yang dikembangkan oleh LIPI;

3. Kelebihan indeks resiliensi yang dikembangkan dalam penelitian ini adalah memperhitungkan indikator sosial dan ekonomi yang berperan didalam menentukan kondisi terumbu karang di kawasan konservasi karena aktifitas masyarakat sangat menentukan kondisi dan potensi pemulihan terumbu karang;

4. Berdasarkan indikator sosial dan ekonomi tersebut maka dapat menjadi acuan bagi pengambil keputusan, dalam hal ini pemerintah daerah, tentang kebijakan yang mengarah pada langkah-langkah yang dapat dilakukan untuk menjaga ekosistem terumbu karang, salah satunya adalah dengan membuka lapangan kerja alternatif selain sebagai nelayan, baik nelayan tradisional maupun nelayan pengguna bius, sehingga diharapkan dapat mengurangi tekanan terhadap ekosistem terumbu karang.

5. Kekurangan dari indeks yang dikembangkan adalah indeks ini dibangun berdasarkan data ekologi, sosial dan ekonomi di P. Pasi Gusung sehingga memiliki keragaan yang baik untuk menilai potensi pemulihan di sekitar perairan KKPD Pulo Pasi gusung, sehingga apabila akan digunakan di daerah atau nasional lain maka dibutuhkan pengambilan data yang bersifat menyeluruh, baik spasial maupun temporal dan pengembangan indeks yang lebih adaptif untuk daerah yang lain. 


\section{UCAPAN TERIMA KASIH}

Travel grant dan akomodasi didalam pengambilan data lapangan oleh Pusat Kajian Sumberdaya Pesisir dan Laut (PKSPL) - IPB

\section{DAFTAR PUSTAKA}

[1] J. E. Cinner, T. R. McClanahan, T. M. Daw, N. A. Graham, J. Maina, S. K. Wilson, et al., "Linking social and ecological systems to sustain coral reef fisheries," Curr Biol, vol. 19, pp. 20612, Feb 102009.

[2] M. Nyström and C. Folke, "Spatial Resilience of Coral Reefs," Ecosystems, vol. 4, pp. 406-417, 2001.

[3] K. R. Anthony, P. A. Marshall, A. Abdulla, R. Beeden, C. Bergh, R. Black, et al., "Operationalizing resilience for adaptive coral reef management under global environmental change," Glob Chang Biol, vol. 21, pp. 48-61, Jan 2015.

[4] S. A. Ali, J. Jompa, and S. Ilyas, "Analisis pemanfaatan ruang dalam pengelolaan wilayah pesisir dan pulaupulau kecil (Studi kasus Pulau Pasi, Kabupaten Kepulauan Selayar)," Universitas Hasanuddin. Makassar, 2011.

[5] COREMAP-Selayar, "Monitoring Kondisi Biofisik Kawasan Konservasi 2016". Benteng: COREMAP-Selayar, 2016.

[6] Giyanto, P. J. Mumby, N. Dhewani, M. Abrar, and M. Y. Iswari, "Indeks Kesehatan Terumbu Karang Indonesia". Jakarta: COREMAP-CTI, Pusat Penelitian Oseanografi LIPI, 2017.

[7] Giyanto, M. Abrar, A. E. Manuputty, R. M. Siringoringo, Y. Tuti, and D. Zulfianita, "Panduan Pemantauan Kesehatan Terumbu Karang", Edisi ke2 ed. Jakarta: Coral Reef Information and Training Center (CRITC), Coral Reef Rehabilitation and Management Program (COREMAP), Pusat Penelitian Oseanografi Lembaga Ilmu Pengetahuan Indonesia, 2017.

[8] S. A. English, C. Wilkinson, and V. J. Baker, "Survey Manual for Tropical Marine Resources", 2nd edition ed.
Townsville: Australian Institute of Marine Science, 1997.

[9] Suharsono, "Jenis-Jenis Karang di Indonesia", vol. 3. Jakarta: Puslit Oseanografi LIPI, 2017.

[10] V. Trygonis and M. Sini, "photoQuad: A dedicated seabed image processing software, and a comparative error analysis of four photoquadrat methods," Journal of Experimental Marine Biology and Ecology, vol. 424-425, pp. 99-108, 2012.

[11] S. R. Suharti, K. Wibowo, I. N. Edrus, and Fahmi, "Panduan Pemantauan Ikan Terumbu Karang", Edisi ke-2 ed. Jakarta: Coral Reef Information and Training Center (CRITC), Coral Reef Rehabilitation and Management Program (COREMAP), Pusat Penelitian Oseanografi Lembaga Ilmu Pengetahuan Indonesia, 2017.

[12] G. Allen, "Marine Fishes of South-East Asia: A Field Guide for Anglers and Divers", 3rd rev. ed ed. Australia: Periplus Editions (HK) Ltd., 1999.

[13] K. Brown, W. N. Adger, E. Tompkins, P. Bacon, D. Shim, and K. Young, "Trade-off analysis for marine protected area management," Ecological Economics, vol. 37, pp. 417 - 434, 2001 